\title{
Family Based Religious Character Education on Posuo Rituals in Baubau Society
}

\author{
Abu Muslim ${ }^{1}$, La Mansi $^{2}$, Mujizatullah ${ }^{3}$, Muh. Subair ${ }^{4}$, Hamsiati $^{5}$ \\ \{abumuslim.litbang@gmail.com¹, lamansi@kemenag.go.id ${ }^{2}$, mujizatullah@kemenag.go.id ${ }^{3}$, \\ ingatbair@gmail.com ${ }^{4}$, hamsiatib@gmail.com ${ }^{5}$ \} \\ Balai Penelitian dan Pengembangan Agama \\ J1. AP. Pettarani No. 72 Makassar ${ }^{1,2,3,4,5}$
}

\begin{abstract}
This paper contains a description of the posuo ritual in the Baubau community. This study aims to explore and understand the values of religious character education contained in the posuo culture in the Baubau community. Collecting data through in-depth interviews, observation and literature study. This research reveals that the posuo ritual is a custom of the people of Baubau City which is very important in shaping the character of girls before marriage so that they have a positive outlook. Posuo aims to be implemented for humanity. In practice, posuo is carried out by teenage girls, who are required to go through posuo before marriage, because in the posuo there is guidance for moral education. Through this moral education, marriage provision is inherited as an important part in the phase of character building in the household system. The contextualization of the posuo is a major part of the continuation of the marriage, which is expected to be a form of inheritance of religious education in the family, with the main hope of forming Sakinah, Mawaddah, wa rahmah. So that the complete knowledge of the inheritance of the posuo is also expected to prevent and / or reduce the divorce rate. Another advantage of holding this posuo ritual is because in the ritual process it can improve the relationship between fellow Baubau City residents. But now, this ceremony is rarely performed by the community, the cause is due to economic factors and lack of socialization. In fact, the posuo ritual is a custom of the people of Baubau City which is very important and significant in shaping the character of teenage girls.
\end{abstract}

Keywords: posuo culture, baubau people, sakinah family education, reducing divorce

\section{Introduction}

The city of Baubau is a beautiful city, full of customs that have been passed down from generation to generation. The exploration of the cultural values of a society that is so developed is, in principle, a mandate of the law, so that many instruments are needed to support the advancement of culture itself, including manifesting specific religious values. As reflected in the Strategic Plan of the Ministry of Religion 2015-2019, research with religious cultural landscapes is expected to provide information for strengthening understanding and inclusive religious practice based on the local community.

The development and exploration of values, as well as religious character, are increasingly filling every public discussion, both in the real world and in cyberspace. In it, it is like expanding the potential of local knowledge that continues to fuse and permeate the sides of our humanity, especially in Indonesia. Therefore, it is necessary to explore values in various aspects of the development of culture itself, because extracting values is always in the shadow of various 
interpretations, depending on the human point of view.

This research was conducted with a focus on tracing the religious values contained in the culture of the community, in this case the city of Baubau, Buton Regency was chosen with the consideration of the significance of local cultural studies that have an adaptive tendency to the times, and other modern regulations, as well as complementing tradition-based religious narratives. There are many, but not specific traditions for teenagers. Of course, this becomes information material for improving the quality of understanding and practice of religious teachings related to cultural values that have the potential to have a character education mouthpiece. The search begins with identifying the interesting and unique culture of society that develops in society by looking at the religious values contained therein.

This attention can be seen in at least one of the 7 elements of universal culture according to C. Kluckhohn in his work entitled Universal Categories of Culture: Language (oral and written), knowledge in society or social organization, livelihoods based on religion, art. [1] Of the seven aspects of culture, the focus of research on cultural societies is limited to include: community rituals, kinship systems, social organizations, political organizations and marriage law systems. The selection of cultural elements to be studied is focused on the peculiarities of community rituals.

One of the Baubau Cultures is Posuo, which is carried out as a means of transitioning a teenage girl's puberty status to adulthood, as well as a mental preparation to be thoroughly prepared for domestic life. Posuo developed in Baubau City, Buton district since the sultanate's rule as a ritual tradition for a pubescent teenage girl (Kabua-bua) to an adult girl (kalambe). The Posuo ritual, as a typical religious-based ritual, is also full of character education values, especially for adolescents before marriage.

The Posuo ritual is carried out as a means of transitioning a girl's status from adolescence (kabua-bua) to adolescent girl (kallambe) to prepare her mentally. The ceremony was held for eight days and eight nights in a special room for the local community called Suo. During their confinement at Suo, the participants were kept away from the influence of the outside world, both from their families and the surrounding environment. Posuo participants can only have contact with Bhisa (the leader of the Posuo ritual). These monks will guide and give advice in the form of moral, spiritual and knowledge of fostering good families to participants.

Seeing the cultural potential contained in this posuo, of course, will make religious normative exploration of the values contained in the entire posuo process allowing us to reap indepth knowledge about the basic meaning of the transition from adolescence to adulthood, as well as seeing what potential is important to emphasize, as is done by local communities. This, to be translated into a modern space, includes how to take the value of the character of religious education in discourse, advice, and doctrinal nuances. Of course all of that requires a comprehensive reading in order to reap the full value of a local ritual whose main essence can be translated into a modern community-based morality education.

Based on this background, this research further examines how the value content of religious character education is extracted from the sublime culture of the Baubau people through Posuo. This formula was then operationalized in 2 research questions, namely (1) How is the development of the Posuo Ritual in the Community in Bau Bau City? (2) How is the value of religious character education reflected in the Posuo Ritual? This study aims to explore and understand the meaning and values of religion contained in the culture of society, to further become a policy material for the development and progress of religious-based national culture.

\section{Literature Review}


As an applied research, several studies on the exploration of religious values in community culture with the same nuances in the last few years will be presented as a comparison. This research can at least be seen in the research conducted by the Jakarta Institute for Religious Research and Development which conducted research on the theme of Religious Values and Harmony in the Oral Traditions of Society in Western Indonesia. One of the research focuses is Agus lswanto [2] in the Journal of Social Science and Religion analysis found that understanding various religious receptions in culture provides a great opportunity to build and maintain harmony among religious followers and to increase solidarity in society.

An article entitled Building Harmony Through Religious Reception In Culture: Lesson Learned From Radin Jambat Folktale Of Lampung reveals the acceptance of religious aspects (the highest truth / God, aspects of cosmological and religious rituals) in the cultural products of Radin Jambat, a folk tale from Lampung, Indonesia. This paper is based on the analysis of Radin Jambat's folk tale texts, interviews, and additional library research from Lampung cultural literary sources. Religious receptions such as those shown in the Radin Jambat folk tale demonstrate the preservation of past beliefs, coupled with the gentle addition and inclusion of Islamic teachings, to create harmony between religion and tradition through folklore. This study is proof that Islam has been accepted by the people of Lampung through a gradual process and various receptions in terms of cultural values. This article shows that the significance of the Radin Jambat folk tale is strong documentation for related sources about the concept and practice of harmony among religious followers in Indonesia in the local Lampung tradition with regard to cultural acceptance.

Still in the same focus, Zulkarnain Yani [3] also presents the results of research conducted in the City of Pagar Alam - South Sumatra by raising one of the oral traditions that still exist in society, namely Tadut. This paper focuses on the study of what religious values are conveyed to the community through Tadut. This study aims to reveal and convey the religious values conveyed in Tadut verses and can serve as guidelines for the community in carrying out their daily beliefs. The results of this study indicate that the tadut oral tradition has religious values, namely the values of tauhid in Islam in the form of pillars of faith and the values of Islamic teachings in the form of the pillars of Islam. The pillars of faith and the pillars of Islam are the religious foundations for the Besemah community in carrying out teachings and worship.

Abu Muslim's research in looking at religious values and tolerance which is reflected in the ritual of burning stones in the land of Papua [4], as well as the rituals of kololi kie and ferekie in Ternate as an accentuation of respect for nature in order to familiarize socially the religious aspects of society, with the surrounding nature [5].

Research on community culture in the form of a thesis, dissertation or research report in tertiary institutions has also been widely carried out. Of course, it is not possible to convey the full results of these studies. This research is in its position to review and complement existing research. In addition, this research position, as one of the studies conducted at research institutions under the Ministry of Religion in order to provide information to policy makers within the Ministry of Religion regarding the potential of religious values for sources of enhancement and development of national culture, as well as an effort to translate the potential Religious character education in the community locality.

\section{Theoretical Review}

The approach used is the phenomenological approach in examining subjective religious facts, as well as the thoughts, feelings, ideas, emotions, experiences, etc. of a person expressed 
in external actions, namely words and actions [6]. In this way, it can also be revealed about the phenomenon of religious culture in traditional societies. The theory used is the functional theory of Thomas F. O'dea.[7] This theory acknowledges the functional contribution of religion to the social system of religion. This theory sees religion as a special culture that influences human behavior and inner and outer. From this functional theory, the functions, values, and roles of community culture that contain religious elements are reviewed.

Functional theory views society as a social institution in balance; who pattern human activities based on shared norms and are considered valid and binding on human participation itself. These complex institutions as a whole are social systems in such a way that each part (each institutional element) is interdependent with other parts so that changes in one part will affect other parts which ultimately affect the condition of the whole system. Functional theory sees humans in society as characterized by two types of needs and two types of tendencies to act. For the sake of survival, humans must act towards the environment, either by adapting themselves or by controlling and controlling it. Functional theory also sees society and social institutions as a system in which all parts depend on each other and work together to create a balance (equilibrium). Attempts to connect as much as possible every feature, custom, practice, which has an impact on the functioning of a stable and cohesive system (Durkheim).

According to Geertz, approaching social events is not just looking for causal relationships, but rather trying to understand the meaning that is lived in a culture. Culture is work that has meaning, that's why culture is semiotic and contextual. Geertz's approach to culture is called a "thick description", which is to interpret symbols of cultural meaning deeply and thoroughly in culture [8]

\subsection{Religious Value}

Value is a feature inherent in an object that is very meaningful in human life (M. Thoha, 1996: 61), especially behavior in doing good to humans (KBBI). Value is something that is abstract, ideal, value is not a concrete object, not a fact, not only a matter of right and wrong that demands empirical proof, but also a social life that is desired, liked, and disliked [9] According to Milton Rekeach and James Bank, value is a belief that falls within the scope of the system. trust someone to act or avoid an action. In religion, values can be useful in three ways, as a basis for the obligation to carry out orders, as a cultural orientation and thought, as a moral tradition. So there are religious values that are commandments and prohibitions, as moral guidelines that regulate human relations with the Almighty, humans with others and humans with nature. Which is based on belief in the Almighty.

Religious values determine what is expected of others based on their religious beliefs. Values are the core principles that guide decision making, helping in determining whether to make decisions about right or wrong, good or bad. Religious values are ideas that are considered good and become teachings derived from the Al-Qur'an and the hadith of the Prophet. Example: Devote to God Almighty, carry out amar ma'ruf and nahi munkar.

\subsection{Community Rituals}

In a cultural context, Posuo rituals are sometimes religious in nature in their implementation because strict conditions must be met by people who have a desire. [10] argues that rituals that are considered sacred have four forms, namely (1) the form of offerings, the complete clothing ritual actors in the ritual procession, (2) ritual behavior (3) Every customary ritual has behavior towards objects that contain hope, meaning, and certain messages delivered to the public. (4) cultural values, namely ideas or ideas that are embedded in the human psyche 
from an early age in the socialization process which are the basis of survival.

Religious rituals contain four main components that must be present in a series of rituals, namely (1) the place for the ritual, (2) the time of the ritual (3) the heirlooms and ritual tools and (4) the person who acts as the ritual performer [11]. Stating that apart from the four main components mentioned above, in traditional rituals there is a combination of various elements such as praying, making promises, sacrificing, eating together, singing, the process of art, fasting, meditating in meditation [12]

\section{Research Methods}

This research was conducted in the city of Bau-Bau by using a qualitative descriptive method to find religious values in the culture of the community, and to describe the various meanings of society towards these values. By choosing one of the cities as the analysis unit, namely Southeast Sulawesi (Buton). Data collection was carried out for 7 exploratory days plus 18 research days. Collecting data using interview techniques, observation, and documentation [13]

The research information consisted of key informants from the government, religious leaders, and traditional leaders. Informants Expert academics, Socio-Cultural Experts, Religious Experts. Informants can be the general public. The analysis used in this research is descriptive in nature, which aims to create a factual and accurate systematic picture of the facts, properties, and relationships between phenomena, although it cannot be separated from the role of the researcher in playing its function as a feature of its main instrument (Sugiyono, 2010: 305). Data analysis used interactive model analysis (Miles, and Hubermas, 1995: 10-14) which took place simultaneously with the data collection process. The stages: Data collection, data presentation, data reduction, and drawing conclusions / verification [14]

\section{Discussion}

\subsection{Posuo Cultural Development in Baubau Society}

Bau-Bau City is a country that has a culture of customs that has been passed down from generation to generation, one of the cultures is posuo/confined. The Butonese know 3 posuo, namely:

1. Posuo wolio, is an early posuo tradition that developed in Buton society.

2. Posuo Johoro from Malayu also developed in Buton

3. Posuo Arabu is a branch of Posuo Wolio.

These three Posuo are in line with the values of Islamic teachings, each of which has different implementation, but the goal is the same, namely that one day it will build a sakinah household ark, mawaddah wa rahmah. This posuo was developed by Syekh H. Abd. Ghaniyyu, the great Ulama of Buton who served as Kenepulu in the Sultanate of Buton, developed in the mid-19th century led by Muhammad Aidrus Qaimuddin Sultan Buton 29th.

Posuo literally comes from the word Suo. Suo means the back room in the traditional house of the Buton people. This space is higher in comparison to other rooms. Suo is the room in the traditional house of the Buton people as the head of the house. The house of the Buton people is a human body, while the inhabitants are soul or spirit. The Posuo tradition is a tradition of pingitan, originally teenage girls who were pinged in suo, so that the tradition of seclusion was called "posuo". (Imran Kudus, interview 4 August 2018 in Kota Baubau). 
Posuo is an intermediate stage ritual for girls who have entered puberty. This ritual does not only apply to the Buton people, but institutionally has a deep meaning in religious ethical values. This ritual has a very solid educational value, especially in implementing ethical values for a girl [15]

The posuo ritual as a means of transitioning the status of adolescent girls who are still girls is carried out by means of a seclusion system, which is basically not intended as a 'locking up' process, but rather a focused educational process in a quiet way, in order to understand more and more deeply the process of inheriting knowledge of knowledge. The stages of the process that are carried out in this posuo, namely when they first enter the ritual, they are still called teenage girls (kabua-bua), and when they graduate or are deemed to have met the requirements, and pass the learning process, they are called kalambe.

The posuo ritual is usually performed just before the wedding for girls. The purpose of holding the posuo is so that a girl during that tenure will receive lessons for debriefing before entering married life (Posuo can be carried out individually or in groups). However, it is not limited to that, but there is a deeper meaning that the posuo ritual is carried out as a means of transitioning the status of a teenager (kabua-bua) to an adult woman (kalambe). During this period of confinement, girls will receive moral, spiritual, advice and important religious values, which are meant so that these girls do not take the wrong steps in facing the future. (Interview with Kari'u H.LM, 25 July 2018).

The pinnacle of coaching teenage girls into adult women through posuo is known as the pauncura (confirmation) process. The path of the pauncura is guided by a Parika / Bhisa, which begins with burning incense, then smokes it, and ends with reciting the prayer of the shahadat of life. In practice, the posuo ritual is carried out individually / in a family, however, recently it is often carried out in groups by the Baubau community. Even though the process of worship in the seclusion room is only filled by a teenage girl so that she is more focused on facing spiritual guidance, moral messages, knowledge about marriage, and how to build a family ark that is safe by the advice.

Another purpose of performing posuo is to test the chastity of a girl. For example, during the posuo ritual, when the drums and gongs are hit and the drum does not break, it indicates that the posuo participants are still holy, but if the drum brakes, it indicates that there are posuo participants among them who are not holy, among the participants there are already having intercourse without going through a marriage contract (Interview with Kari'u, the former Imam of the Buton Kraton Mosque). However, whatever results from the procession of beating the gong will not be published, but only known by the family and drum experts. This tradition lasts for eight days and nights in a suo (special room).

When a girl performs posuo she will be bound and removed from various influences from the outside world. The girl can only relate to the bhisa / educator / coach. Educators are people who are directly appointed by customary leaders to provide various special education / teaching during the posuo period. In the implementation there is someone who beats the drums and gongs (drum handlers).

Posuo rituals are closely related to belief. Beliefs and ritual actions are complementary elements of religion. Posuo is one of the community rituals that have a social tendency and are vertical-horizontal between God and humans. Posuo has a function of strengthening social ties, as a medium for character education, especially for girls who are about to reach puberty, as an initial preparation for facing the challenges of life's twists and turns, which are far different from the atmosphere they faced in childhood. Posuo becomes an integral part of customs and as a future strength and strategy, which a woman must prepare to face the future to plan life changes and adjustments. 
Posuo serves as a medium for mental education for young women, very relevant to current conditions. It is necessary to strengthen the value of morality among adolescents, who are vulnerable to the influence of global culture and modernity [16]. The Order for the Implementation of the Posuo Ritual is an agreement of Sufism scholars in Buton. It is likened to the philosophy of the posuo participant as if he were a child born by Bisha, so the movements directed by a Bhisa to a posuo participant are like caring for a newborn. Then in the application of implementing this posuo by looking at examples of the birth of the Prophet, so that in the process of Posuo being regulated and approved by the religious leaders of Tasawuf, 4 conditions were carried out, namely:

1. Posuo two Nights. Even though it is called Posuo for two nights, it is basically done for 3 nights, because the first night is nights of sobs, as a mirror of emotion and happiness, but the days have not been counted. The two-night posuo was inspired by the example of Muhammad Al-Hanafi's pregnancy, he had the same knowledge as a Wali.

2. Posuo for 4 nights, means it is done for 5 nights because the first night is the night of sobs. Posuo 4 tonight imitates the Prophet Muhammad because he was impregnated for 9 months.

3. Posuo for 6 nights, means that it is performed for 7 nights because the first night is just a night of crying. Posuo 6 nights is meant to emulate the pregnancy of Prophet Al-Isa because he was 2 years in the womb and just born.

4. Posuo 8 nights, means that it is done for 9 nights, because the first night is just a night of crying. This Posuo exemplifies the pregnancy of Prophet Al-Idris, because he was 4 years in the womb and then was born. The implementation of Posuo is a minimum of 2 days / night and a maximum of 8 days / night.

Materials to prepare for the Posuo / Pingitan Room Entry:

1. Pulawu (Pillow), Kiwalu (Mat) and timbasa (White Cloth) 4 pieces each 2 meters. This cloth is used on the 5th night as a base when using wet turmeric powder, as a plapon ceiling, as a seat, and as a cover for flower water that is stored for 4 nights. Then the next 4 nights the turmeric powder was replaced with a white powder made from rice flour.

2. Bringing Siri, Areca Tobacco, Lime and Gambir stored in a Toba basket as equipment for the ritual of smoking the Posuo participants. The purpose of siri, areca nut, tobacco, lime, and gambier is to strengthen teeth.

3. Bringing Katibo (areca flower wrap) to be used as a cushion while smoking, (this smoking is a condition for entering the seclusion room), when he has entered he can no longer leave before the specified time. This process is done to nourish the feminine area.

4. Bringing 2 Kapopore (baskets) each Posuo,

a. Kapopore contains 1 small plate of rice, 1 bowl contains 4 pieces of cooked fish, 2 pieces of diamond as big as a baby bolster pillow, then kapopore is covered with a white cloth.

b. Another Kapopore contains: a coconut shell bowl filled with fried rice and 4 pieces of fish, and 8 small diamonds with a size of $5 \times 5 \mathrm{~cm}$, used on the 8 th day / last day.

The agreement on the number of days for the implementation of Posuo depends on the conversation between the parents and the traditional authorities ( 2 days / 2 nights, 4 days / 4 nights, 6 days / 6 nights and 8 days / 8 nights). Every night the rate is two boka / person for the 
public. One boka is equivalent to Rp. 60.000, - (Kari'u, Former Imam of the Great Mosque of the Karaton, Interview 25 July 2018).

Waode wife La Uge (a Butonese traditional / religious figure) argued that carrying out seclusion like this had to be really ready, because on the 8th (last) day many officials were invited, even announced to the community in one village. Therefore there needs to be readiness of funds. This also makes some Butonese people unable to carry out this ritual for economic reasons.

Some of the rules that must be followed in the posuo ritual include:

a. Participants may not leave the house during the period of stay. While in seclusion.

b. Eating is limited to only 2 times a day and night, and even then only eat a small plate plus one egg.

c. There are rules for sleeping positions, namely on the first to fourth nights, the head is to the west.

d. On the 5-8th night the posuo participants hold a Baliana Yimpo (reversing the direction of sleep), so that the position of the head is in the east at the order of Bhisa. This change is perceived in the ritual of seven months from a mother's pregnancy, pregnancy is in the middle of the journey to birth, prayed for easy delivery by reading "salawat live" ( Allahumma shalli ala syaidina Muhammad, wa ala ali syaidina Muhammad). That is why, in implementing Posuo, one of the philosophies is to humanize humans.

\subsection{Before Entering The Room}

a. Posuo participants are taken around 2 hours before they enter the seclusion room.

b. Posuo participants are smoked by the supervisor (Bisha) as a condition for entering the room, namely Posuo sits on a Kamboti (skin covering the areca nut) then the supervisor (bashia) lights a fire on an earthen plate, after the fire is burning then sprinkled with kemenyang (fire fragrance) ) Then Bashia's palms took the smoke from the fire and wiped them on the posuo participant's right hand from the tip of the finger up to the shoulder

c. The first night was the night of sobs

When Posuo was in the seclusion room on the first night, the posuo participants were made to cry by performing several bhisa methods; pinching, so the first night is called the night of crying, all posuo participants are made to cry and eat limited, only 2 times, in a day and night, given piri-piri (eating a small plate of rice with one egg and a small glass of water). The posuo participants are given a little food to remind them that there are still many people who cannot make ends meet, only eat little or some don't even eat.

d. Use turmeric scrub for 4 days. After all of their bodies have been stretched out, they are then asked to move their limbs, as well as exercise. This is done after every bath by the bhisa or posuo coach. People who do not meditate on the value of their priest are weak because they are not grateful for the blessings of God giving to children.

e. Use a white powder scrub made of flour mixed with henna leaves for 4 days. The posuo participants use turmeric powder and white powder scrubs made of rice flour as symbolism (they have to keep their skin smooth and it must be used after they leave suo. That's how women are taught to maintain their beauty).

f. On the 5th day of the day they are able to defecate, the posuo participants can bathe in western water and eastern water.

g. On that night they were dressed in traditional clothes (traditional clothes) and the next day, the ritual of treading the land by the coach or traditional shop, after they were 
finished they could go home.

\subsection{Posuo Day 9}

a. Bathing in western water and eastern water. This water is taken at the confluence of a river with the sea, the water flows, it is collected at 12.00 at night, no one knows and sees it except the person who takes it. Two gallons facing the buttocks, one facing west and one facing east, gallons facing west are considered male water, and gallons facing east are considered female water. Then drowned together. Then the person who takes this water must be a man who is still alive with both parents and is healthy.

b. Water is taken from the well at 12.00 at night or in a water storage place by a man whose parents are both still alive. Water mixed with fragrant flowers.

c. Wear komboh clothes (complete traditional clothes then sit in a place that has been prepared for the process of stepping on the land, the land is taken from the kabalai pole (the first pole which is considered the center of the house) who take this land is not just anyone, but a boy who is still living second After finishing the treadling of the land, the head coach or bhisa recites a congratulatory prayer. Then after that they return to their respective homes.

Especially for participants who are getting married soon, the water to be bathed is mixed with chrysanthemum and frangipani flowers. The water comes from a different spring. People who take water are not arbitrary, it must be men who still have a father and mother. The climax of the ritual is after they are bathed and then dressed in a special outfit known as ajo kalembe dress. After that the participants were allowed to leave the room which indicated the girls were adults. The Butonese believe that a teenager who does not do posuo and then gets married, is considered weak in faith, susceptible to skin disease, and through the Posuo process we are oriented to always be grateful for the blessings of Allah, namely children (Interview with Drs. LM. Kari'u, Figure Religion and Society, former Imam of the Karaton Mosque, July 26).

\subsection{Religious Value Contained In The Posuo Culture}

Posuo rituals are generally carried out in the month of Shawwal, Ramadhan or Dzulhijjah depending on the opportunity of the people who wish. This ritual is included in the Buton Manuscript, this manuscript is a copy copied from the original 1972 AD book by Drs. H. LM. Kari'u.

The development of Posuo culture in Buton society is very supportive because this Posuo activity is an effort to improve the morality of teenagers. All cultures are related to religion and are related to each other [17]. Improving the morality of adolescents is a concern of the community, so that in general the implementation of posuo culture is carried out by the community in Baubau City.

Posuo which is a tradition of the Baubau people in practice reflects religious values. This religious value is reflected in the cultural practices of the local community, especially in the posuo ritual. The values in question are:

Moral values. When a teenage girl will be married off and a posuo ceremony procession is performed, the girl will be put in a suo. In the suo, they will be taught about how to be ethical or have good behavior in their daily life after marriage. They will be introduced to the duties of a wife, as well as how a wife's ethics is towards her husband, loyalty to her husband, daughter-inlaw's ethics towards in-laws, ethics in society, sexuality education, etc.

Although in general teenage girls in Baubau are taught from an early age how to help their parents at home, so they generally help with household chores such as cooking, washing, 
cleaning and how to behave towards older people, it is not uncommon for them to behave inappropriately., often hang out with his friends without knowing the time, mock each other, and they do not know various kinds of homework.

Therefore this posuo ceremony plays an important role in improving the behavior of these teenage girls, so that after they finish at the posuo ceremony they will become better and aware of their duties later. And they are ready both physically and mentally to enter the household ark to build a sakinah, mawaddah, wa rahmah family.

The value of worship. In the procession of the posuo ritual, it begins with praying and dhikr and reciting prayers that are praised to the Messenger of Allah Muhammad SAW., Which aims to pave the way for teenage girls before moving to the next level, namely a new life as an adult girl.

The value of solidarity. The posuo ceremony involves several people or families, so that in practice, they will work together with one another to continue to preserve this culture. Before determining the timing of the ceremony, they held a deliberation to discuss the timing and tools used in connection with the posuo ceremony and other matters related to the ceremony so that the community togetherness value in preparing the posuo ceremony was seen.

Value of beauty. In the process, teenage girls who become posuo participants will be taught how to take care of themselves with scrubs using natural ingredients such as turmeric and rice. They are also taught to maintain posture by limiting their eating (diet). So that they will always look beautiful to look at.

\section{Closing}

Posuo rituals are customs of the people of Baubau City, which are very important in shaping the character of girls who have entered the age of marriage, to be able to provide good moral understanding and knowledge based on Buton customs as provisions so that later when they can navigate their domestic life can run well, and avoid all kinds of problems.

This posuo ritual is very important to be encouraged, in order to make it a shield against the behavior of teenagers who have recently become very apprehensive and have even fallen into promiscuity. Posuo is also an embodiment of preserving the sanctity of women before marriage, which can also inspire or invite people to live side by side wisely. Posuo can also be translated as traditional training for girls, which is even more complex than the more formal SUSCATIN.

If Posuo can be encouraged and nurtured, understood its meaning and purpose, and managed well in line with the traditional spirit inherent from a long time ago, then it is not impossible that the implementation of Posuo will help reduce the number of divorces.

This ritual shows the potential religious value of fostering solidarity and cooperation in order to strengthen harmonious relations between humans and other humans, as well as between humans and nature and their environment. This in turn can be used as an important part in terms of advancing culture, especially in terms of developing a culture-oriented National Education. Apart from that, the aspects of mutual cooperation and solidarity can at least be used as inspiration for conflict resolution, as well as in terms of the servitude of beings to their creators.

The various social and religious values then show how rich and very meaningful the cultural treasures of the archipelago are. So that the context of the tradition with its deep meaning is very important to be adopted by religious extension workers in providing education to the community.

The values that are explored in this community tradition can at least be an important part in relation to the advancement of culture, conflict resolution, and inspire the enrichment of 
curricula in educational media. In addition, the integration of religious values into other aspects of community life is an important part of the formulation of recommendations for this study, including: 1) In relation to cultural advancement, the points of preserving the values in Posuo include mutual cooperation and solidarity, and building harmony between communities is an integral part of strengthening local cultural values. Technically, this can be done through the Protection, Development, Utilization and Fostering of each of these traditions as local traditions belonging to Indonesian Indonesian-owned Buton. 2) Posuo a promising tradition of social harmony that has implications for the cultivation of noble values and religious culture to the young generation that can be integrated with the material Petite bride (SUSCATIN) at KUA. 3) Religious values and social wisdom contained in the Posuo ritual can become teaching points that can be included in the content of the local education curriculum in Buton.

\section{References}

[1] Koentjaraningrat: Kebudayaan Mentalitas dan Pembangunan. Jakarta: Gramedia. Pustaka Utama. pp. 203-204 ( 1994)

[2] Iswanto, Agus: Building Harmoni' Through Religious Reception In Culture: Lesson Learned From Radin Jambat Folktale Of Lampung. Analisa Journal of Social Science and Religion, Volume 02 No. 02 December 2017. Religious Research and Development, Ministry of Religious Affairs, Semarang. (2017)

[3] Yani, Zulkarnain: Nilai-Nilai Keagamaan Dalam Tradisi Lisan Tadut Di Kota Pagar Alam Sumatera Selatan. Jurnal PENAMAS Volume 30, Nomor 1, April-Juni 2017. pp. 71-84 Balai Penelitian dan Pengembangan Agama Jakarta. (2017)

[4] Muslim, Abu: The Harmony Taste Of Bakar Batu Tradition On Papua Land. Heritage of Nusantara: International Journal of Religious Literature and Heritage Volume 8 Nomor 1 Tahun 2019. Puslitbang Lektur dan Khazanah Keagamaan Badan Litbang dan Diklat Kementerian Agama RI. (2019)

[5] Idham and Abu Muslim:. Islamic Values In The Traditional Rituals Of Kololi Kie And Fere Kie. Social And Climate Changes In 5.0 Society, 111. (2019)

[6] Imam Suprayogo and Tobroni: Metodologi Penelitian Sosial-Agama, Bandung: Rosdakarya. pp. 103 (2003)

[7] Thomas F. O'dea: Sosiologi Agama, terj. Tim Yasogama, Jakarta: Raja Grafindo Persada. pp. 11 (1996)

[8] Geertz, Clifford: The Interpretation of Cultures. Hutchinson: London. [Terjernah] Tafsir Kebudayaan. Translator: Francisco Budi Hardiman. Yogyakarta: Kanisius. (1992)

[9] Isna, Mansur: Diskursus Pendidikan Islam. Yogyakarta: Global Pustaka Utama. pp.98 (2001)

[10] Koentjaraningrat: Kebudayaan Mentalitas dan Pembangunan. Jakarta: Gramedia. Pustaka Utama. ( 1994)

[11] Koentjaraningrat: Kebudayaan Mentalitas dan Pembangunan. Jakarta: Gramedia. Pustaka Utama. ( 1994)

[12] Koentjaraningrat: Kebudayaan Mentalitas dan Pembangunan. Jakarta: Gramedia. Pustaka Utama. pp. 240 ( 1994)

[13] Cresswell, Jhon W.: Research Design, Qualitative and Quantitative Approaches. California: Thousand Oaks (1994)

[14] S. Nasution.: Metode Penelitian Naturalistik- Kualitatif. Bandung: Tarsito (1992) 
[15] Alifuddin Muhammad: Signifikansi Upacara Silkus Posuo Dalam Membangun Semesta Keperibadian Remaja Wanita pada Masyarakat Buton, Fak. Uhsuluddin, Adab dan Dakwah. pp.1

[16] Alifuddin Muhammad: Signifikansi Upacara Silkus Posuo Dalam Membangun Semesta Keperibadian Remaja Wanita pada Masyarakat Buton, Fak. Uhsuluddin, Adab dan Dakwah. pp.4

[17] La Ode Abdul Munafi, Andi Tenri, La Ode Muh. Nasru, and Rustan Awat: Budaya Buton. Penerbit BAPPEDA Kota Bau Bau (2015) 